\title{
Storage and germination of seeds of Handroanthus heptaphyllus (Mart.) Mattos ${ }^{1}$
}

\author{
Thaíse da Silva Tonetto ${ }^{2 *}$, Maristela Machado Araujo², Marlove Fátima Brião \\ Muniz ${ }^{3}$, Clair Walker ${ }^{3}$, Álvaro Luís Pasquetti Berghetti²
}

\begin{abstract}
The aim of this study was to determine the substrate and the most suitable sowing method for germination, as well as the environment for storage of Handroanthus heptaphyllus seeds (ipê-roxo), and infer the health quality provided by different packaging. Experiment 1 has assessed the treatments (substrates - blotting paper, filter paper, vermiculite, sand, besides paper roll; and sowing methods - among and on the substrates). Experiment 2 has assessed storage in three environments (air conditioned room $-18{ }^{\circ} \mathrm{C}$ and $49 \%$ of relative humidity (RH); cold and wet chamber $-8{ }^{\circ} \mathrm{C}$ and $80 \%$ $\mathrm{RH}$; and dry and cold chamber $-7.5^{\circ} \mathrm{C}$ and $55 \% \mathrm{RH}$ ), for 300 days. Handroanthus heptaphyllus seed germination test can be performed using seeding among blotting paper, vermiculite, on sand, between sand, on vermiculite and between filter paper. The storage of the seeds in plastic bags kept in an air conditioned room and/or in a dry and cold chamber is suitable for the preservation of Handroanthus heptaphyllus seeds for a period of 300 days. The packaging in a dry and cold chamber environment has provided a lower incidence of fungi associated with the Handroanthus heptaphyllus seeds.
\end{abstract}

Index terms: ipê-roxo, germination potential, storage.

\section{Qualidade de sementes de Handroanthus heptaphyllus (Mart.) Mattos armazenadas em diferentes ambientes}

\begin{abstract}
RESUMO - O objetivo desse estudo foi determinar o substrato e o método de semeadura mais adequado para a germinação, assim como, o ambiente para o armazenamento de sementes de ipê-roxo (Handroanthus heptaphyllus), além de inferir sobre a qualidade sanitária proporcionada pelos distintos acondicionamentos. No experimento 1 foram avaliados os tratamentos (substratos - papel mata-borrão, papel filtro, vermiculita, areia, além do rolo de papel; e métodos de semeadura - entre e sobre os substratos). No experimento 2 foi avaliado o armazenamento em três ambientes (sala climatizada $-18{ }^{\circ} \mathrm{C}$ e $49 \%$ umidade relativa (UR); câmara fria e úmida $-8{ }^{\circ} \mathrm{C}$ e $80 \%$ UR; e câmara seca e fria $-7,5^{\circ} \mathrm{C}$ e $55 \%$ UR), por 300 dias. O teste de germinação de sementes de Handroanthus heptaphyllus pode ser realizado utilizando-se a semeadura entre papel mata-borrão, entre vermiculita, sobre areia, entre areia, sobre vermiculita e entre papel filtro. $\mathrm{O}$ armazenamento das sementes em sacos de plástico mantidos em ambiente de sala climatizada e/ou em câmara seca e fria é adequado à conservação das sementes de Handroanthus heptaphyllus por um período de 300 dias. O acondicionamento em ambiente de câmara seca e fria proporcionou menor incidência de fungos associados às sementes de Handroanthus heptaphyllus.
\end{abstract}

Termos para indexação: ipê-roxo, potencial germinativo, armazenamento.

\section{Introduction}

The need for maintenance and conservation of native forest species has become evident given the intense social and scientific concern for recovering degraded areas. Thus arises the need for further studies that subsidize information to qualify the yield of those species. According to Sarmento and Villela (2010), society's concern strengthens the

${ }^{1}$ Submitted on 10/08/2014. Accepted for publication on 01/21/2015 ${ }^{2}$ Departamento de Ciências Florestais, Centro de Ciências Rurais, Universidade Federal de Santa Maria, 97105-900 - Santa Maria, RS, Brasil. environmental policies to promote greater demand for seeds and seedlings of native forest species, which are a basic input for conservation programs, recovery of ecosystems, plant improvement and biotechnology.

The characteristics of the seeds should be assessed by physical, physiological and health tests in order to prove the quality of the lot, as well as provide information on which to base the seeds sowing and preservation. The procedures 
for such tests are described in the Regras para Análise de Sementes (Rules for Seed Analysis) (Brasil, 2009a; 2009b) and Instruções para Análises de Sementes de Espécies Florestais (Instructions for Analyses of Forest Species Seeds) (Brasil, 2013). Accordingly, knowing which substrate provides a suitable seed germination is needed, since it varies depending on the species, compromising the analysis result on the quality of the seeds. Brasil (2013) suggests the paper roll substrate for Handroanthus heptaphyllus.

The importance of studies related to Handroanthus heptaphyllus seeds is enhanced by the fact that their spread is mainly by seeds, requiring its preservation in periods in which there is no fruit. Thus, the seed storage is shown as an important tool to remedy possible deficiencies in the production of seeds and seedlings, and, according to MarcosFilho (2005), the preservation period of the physiological potential depends in large part on the water content of seeds and storage conditions.

It is noteworthy that among the information in the literature, there is divergence with respect to tolerance to storage and maintenance of quality of seeds of the species Handroanthus heptaphyllus (Lorenzi, 2002; Carvalho et al., 2006; Grings and Brack, 2011), which becomes a barrier to ensure the seed preservation. Thus, opposition is observed in studies on the species and genus. In addition, it is necessary to ensure that the supply of seeds be free of pathogens, since their presence can reduce the germination ability of a lot. Among the studies on seed health of the genus Handroanthus, the one by Botelho et al. (2008) stands out, who have observed the presence of Alternaria sp., Aspergillus sp., Fusarium sp., Cladosporium sp., Penincilium sp., among others.

Handroanthus heptaphyllus (ipê-roxo), belonging to the Bignoniaceae family, is widely distributed in Brazil from southern Bahia to Rio Grande do Sul, and that, according to Lorenzi (2002), has a large timber and ecological value. Thus, ipê-roxo emerges as a priority for studies because it is adapted to the soil and climate conditions of much of Brazil.

The germination of ipê-roxo seeds is fast, because it does not have dormancy (Lorenzi, 2002), has a high germination potential $(71.8 \%)$, and the seeds are classified as orthodox (Wielewicki et al., 2006). On the other hand, Grings and Brack (2011) point out that this species produces lots of seeds with high viability; however, they should be sown right after harvest, since they lose the germination ability in a few weeks if they are not preserved in cold or dry storage.

Borba Filho and Perez (2009), assessing the storage of seeds of Handroanthus roseo-alba (ipê-branco; tabebuia roseoalba, known as white ipê, ipê-branco or lapacho blanco) and Handroanthus impetiginosus (ipê-rosa) in different packaging, have found that packaging in cans and preservation in refrigerators (4 to $6{ }^{\circ} \mathrm{C}$ and 38 to $43 \% \mathrm{RH}$ (relative humidity)) were favorable to the preservation of the seeds of both species, with germination around $80 \%$ at 300 days of storage.

The objective of this study was to determine the substrate and the most suitable sowing method for germination, as well as the environment for storage of ipê-roxo (Handroanthus heptaphyllus) seeds, and infer the health quality provided by different packaging.

\section{Material and Methods}

Ripe fruits of Handroanthus heptaphyllus were collected in eight trees in December 2011, in the region of Santa Maria, RS, Brazil (29 47'37'S and 53\%40'01'O). The seeds analyses were carried out at the Laboratório de Silvicultura e Viveiro Florestal and at Laboratório de Fitopatologia Elocy Minussi at Universidade Federal de Santa Maria (UFSM), Santa Maria, RS, Brasil.

For processing the fruits and seeds, they were stored in a shaded and airy shed to complete their opening and release the seeds. Thereafter, the processing was performed in order to separate impurities and damaged seeds. Then the lot to be studied was made, which was divided into two sub-lots, one for experiment 1 and the other for experiment 2.

\section{Experiment 1 - Lot characterization and study of a suitable substrate for determination of seed physiological quality}

The weight of one thousand seeds was performed according to Regras para Análise de Sementes (Rules for Seeds Analyses) (RAS), using eight replicates of 100 seeds (Brasil, 2009a). The water content of the seeds by the oven method $\left(105 \pm 3{ }^{\circ} \mathrm{C}\right.$ for $24 \mathrm{~h}$ ) with four replications of 25 seeds (Brasil, 2009a).

For analysis of the electrical conductivity, the mass method was used. The four samples, each consisting of 25 seeds, were first weighed on a digital scale accurate to 0.001 $\mathrm{g}$, and then placed into $200 \mathrm{~mL}$ plastic cups, which were immersed in $75 \mathrm{~mL}$ of distilled water for 24 hours and then placed in a germination chamber at $25{ }^{\circ} \mathrm{C}$, with the cups covered with foil (Vieira, 1994).

After 24 hours, homogenization of the solution was done, and then electrical conductivity (EC) was measured for the deionized water in order to calibrate and adjust and for the seed samples. The results were expressed in $\mu \mathrm{S} / \mathrm{cm}^{-}$ $1 / \mathrm{g}^{-1}$, obtained by subtracting the EC of the seed sample from the EC of the distilled water and dividing the result of this subtraction by the weight of the seed sample. 
Substrate analysis suitable for germination and initial physiological quality of the seeds

The analysis of the initial physiological quality (time zero) of the seed lot was accomplished by means of the germination test in gerbox-type transparent plastic boxes with four replications of 25 seeds, testing the following treatments: $\mathrm{T} 1$ - on blotting paper, T2 - between blotting paper; T3 - on filter paper, T4 - between filter paper; T5 - on vermiculite; T6 - between vermiculite; T7 on sand; T8 - between sand and T9 - paper roll, which has totaled 36 sampling units.

For the amount of water to be added in the "sand" and "vermiculite" treatment, the methodology proposed by Brasil (2009a) and Brasil (2013) was respectively considered, adding a water volume for $60 \%$ of field capacity. The other treatments with paper substrate were moistened with 2.5 times the weight of the paper. All substrates and the distilled water were autoclaved $\left(120^{\circ} \mathrm{C}\right.$ for $\left.2 \mathrm{~h}\right)$, and the gerbox with alcohol $70^{\circ} \mathrm{GL}$ (degrees Gay-Lussac (after the French chemist Joseph Louis Gay-Lussac).

The seed disinfection was performed with five drops of neutral detergent diluted in $100 \mathrm{~mL}$ of distilled water for 5 minutes, being subsequently rinsed three times in distilled water (Brasil, 2011). Then the seeds were placed in the treatments, with samples being taken to a Mangelsdorf-type germination chamber $\left(25 \pm 3{ }^{\circ} \mathrm{C}\right.$ and constant light $)$, which was kept in an air conditioned room $\left(25^{\circ} \mathrm{C}\right)$.

The counts were taken every three days until the end of the test. The technological criteria of normal seedling formation was used (Brasil, 2009a). From these data, the percentage of normal seedlings, abnormal seedlings, firm seeds (hard) and dead seedlings was calculated, obtaining information on the first and last count, and the germination speed index (Maguire, 1962).

\section{Experiment 2 - Quality analysis of the stored seeds in different environments}

For the analysis of the seeds before storage, the data obtained in experiment 1 were used. Storage of Handroanthus heptaphyllus was held in December 2011 in sealed polyethylene bags of 10 microns, containing $135 \mathrm{~g}$ of seeds ( $\cong 3000$ seeds). They were placed in Kraft paper drums, staying in three rooms (treatments) during 300 days (until October 2012). Thus, the treatments consisted of: $\mathrm{T} 1$ - air conditioned room $\left(18 \pm 3{ }^{\circ} \mathrm{C}\right.$ and $49 \pm 10 \%$ relative humidity - RH); T2 - wet and cold chamber $\left(8 \pm 2{ }^{\circ} \mathrm{C}\right.$ and $\left.80 \pm 10 \% \mathrm{RH}\right)$; T3 - dry and cold chamber $\left(7.5 \pm 1.5^{\circ} \mathrm{C}\right.$ and $\left.55 \pm 10 \% \mathrm{RH}\right)$, which have been compared to T4, which has constituted the time zero (without storage).
For the tests, initially the seeds of each treatment were homogenized (storage). Afterwards, the working sample was obtained for determining the weight of a thousand seeds, the water content of the seeds and the electrical conductivity, using the same methods used in experiment 1 . Germination tests were installed adopting the "on sand" treatment, with four replications of 25 seeds for each storage, following the same procedure as in experiment 1.

Along with that, after storage, at 300 days the presence of fungi associated to the Handroanthus heptaphyllus seeds by the health test was assessed. First, the gerboxes were disinfected with a sodium hypochlorite $1 \%$ and alcohol $70 \%$ solution, were covered with two sheets of sterile filter paper dampened with sterile distilled water and then the seeds were distributed on the paper (Brasil, 2009b). Four replicates of 25 seeds for each treatment were used. Incubation was performed in a chamber with a controlled temperature $\left(25 \pm 2{ }^{\circ} \mathrm{C}\right.$ and a photoperiod of 12 hours of light using six fluorescent lamps) for seven days. After this period, the identification and quantification of the fungi under stereoscopic and optical microscope were performed, according to Barnett and Hunter (1999).

For the experiments, a completely randomized experimental design was used. The data then went through normality tests of waste and homogeneity of variances by means of the Shapiro-Wilk and Bartlett tests, respectively. In case any of these assumptions had not been met, the processing of the data was performed in an arcsine $(\mathrm{X} / 100)^{0,5}$ for data in percent and for the others $(\mathrm{x}+0.5)^{0,5}$, where $\mathrm{X}=$ variable (Santana and Ranal, 2000).

Statistical analysis was performed with the aid of software SISVAR (Ferreira, 2011), subjecting the data to analysis of variance, and when a discrepancy between the treatments by the F test $(p<0.05)$ was noticed, the comparison of means by Student's $t$ and Scott-Knott tests at $5 \%$ of error probability was performed.

\section{Results and Discussions}

The seeds of Handroanthus heptaphyllus have presented initial figures (time zero) for the weight of 1000 seeds of $45.8 \pm 0.10 \mathrm{~g}$ (coefficient of variation $-\mathrm{CV}=2.24 \%$ ), which represents, on average, 21,834.06 seeds $/ \mathrm{kg}^{-1}$. Similarly, the water content of the seeds (WC) was of $8.79 \pm 0.32 \%(\mathrm{CV}$ $=3.66 \%$ ).

In the germination test $(\mathrm{G} \%)$ the highest values were obtained in the treatment between blotting paper (BBP), between vermiculite (BV), on sand (OS), between sand (BS), on vermiculite $(\mathrm{OV})$ and between filter paper (BFP) (Table 1). 
Table 1. Normal seedlings (G), germination speed index (GSI), abnormal seedlings (AS), dead seeds (DS) and hard seeds (HS) of Handroanthus heptaphyllus (Mart.) Mattos, on different substrates at time zero.

\begin{tabular}{cccccc}
\hline Treatment & G (\%) & GSI & AS (\%) & DS (\%) & HS (\%) \\
\hline OBP & $48 \mathrm{c}^{*}$ & $0.64 \mathrm{c}$ & $31 \mathrm{a}$ & $19^{\text {ns }}$ & $2^{\text {ns }}$ \\
BBP & $84 \mathrm{a}$ & $1.51 \mathrm{a}$ & $0 \mathrm{~b}$ & 16 & 0 \\
OPF & $64 \mathrm{~b}$ & $0.82 \mathrm{~b}$ & $17 \mathrm{a}$ & 19 & 0 \\
BFP & $77 \mathrm{a}$ & $1.32 \mathrm{a}$ & $1 \mathrm{~b}$ & 22 & 0 \\
OV & $79 \mathrm{a}$ & $1.39 \mathrm{a}$ & $2 \mathrm{~b}$ & 19 & 0 \\
BV & $83 \mathrm{a}$ & $1.50 \mathrm{a}$ & $1 \mathrm{~b}$ & 16 & 0 \\
OS & $83 \mathrm{a}$ & $1.52 \mathrm{a}$ & $1 \mathrm{~b}$ & 16 & 0 \\
BS & $81 \mathrm{a}$ & $1.43 \mathrm{a}$ & $3 \mathrm{~b}$ & 16 & 0 \\
RP & $64 \mathrm{~b}$ & $1.01 \mathrm{~b}$ & $6 \mathrm{~b}$ & 29 & 1 \\
\hline Average & 74 & 1.24 & 6.89 & 19.11 & 0.33 \\
\hline CV (\%) & 13.04 & 15.45 & 86.92 & 42.78 & 447.21 \\
\hline
\end{tabular}

*Means followed by the same letter do not differ statistically at $5 \%$ of error probability by Scott-Knott test; ns = non-significant; $\mathrm{CV}=$ coefficient of variation; OBP (on blotting paper); BBP (between blotting paper); OPF (on filter paper); BFP (between filter paper); OV (on vermiculite); BV (between vermiculite); OS (on sand); BS (between sand) and RP (paper roll)

The treatments mentioned before have differed from the treatment on filter paper (OFP), paper roll (PR) and on blotting paper (OBP), and, in the latter, $48 \%$ of the seeds have germinated, and therefore were considered unsuitable for germination analysis of ipê-roxo (Table 1) because they do not reflect the actual quality of the seeds because in the other treatments there was a germination with higher percentages.

The assessment of the germination speed index (GSI) has corroborated the results observed in germination, which have indicated as superior the treatments: $\mathrm{BBP}, \mathrm{BV}, \mathrm{OS}, \mathrm{BS}, \mathrm{OV}$ and BFP (Table 1), which also allows us to infer that the vigor can be expressed by these treatments.

Analysis of the percentage of abnormal seedlings (AS) in the experiment course make it possible to infer that the OBP $(31 \%)$ and OPF $(17 \%)$ treatments account for the higher values of abnormalities, intensifying the understanding that these are not suitable for germination of ipê-roxo seeds. The percentage of dead and hard seeds was not significant at the $5 \%$ error probability for the different treatments assessed (Table 1). The high mortality rates of seeds in all treatments may be related to the presence of fungi, a fact that suggests the need to identify the pathogens associated with the seeds.

Accordingly, the use of the treatment on sand (Table 1) is indicated, which, besides a high germination and GSI, can be more easily worked on. Therefore, it was selected for performing experiment 2 .
Quality analysis of the seeds stored in different environments

After storage (300 days) in the different environments (air condition room - ACR, wet and cold chamber - WCC and dry and cold chamber-DCC), the figures for the weight of 1000 seeds (WTS) were $32.20 \pm 0.07 \mathrm{~g}(\mathrm{CV}=1.92 \%)$, $36.46 \pm 0.21 \mathrm{~g}(\mathrm{CV}=5.71 \%)$ and $36.69 \pm 0.18 \mathrm{~g}(\mathrm{CV}=$ $4.93 \%$ ), in each storage environment, representing $31,055.90$; $27,427.32$ and $27,255.38$ seeds $/ \mathrm{kg}^{-1}$, respectively. It is shown that the water content (WC) of the seeds in the different environments (air conditioned room, wet and cold chamber, dry and cold chamber) was, respectively, 7,67 $\pm 0,47 \%(\mathrm{CV}=$ $6.16 \%) ; 10.41 \pm 0.94 \%(\mathrm{CV}=9.07 \%)$ and $9.29 \pm 0.37 \%(\mathrm{CV}$ $=3.96 \%)$. The moisture content $(\mathrm{MC})$ has declined relative to time zero only for air conditioned room, because for wet and cold chamber and dry and cold chamber there was an increase in the moisture content of the seeds. In the case of the wet and cold chamber, the result can be related to the high relative humidity $(80 \%)$ occurring to the moisture absorption by the seeds, because the packaging used for storage is semipermeable (polyethylene plastic). A similar situation may have occurred in the dry and cold chamber.

The highest germination has occurred for non-stored seeds (NS $=83 \%$ ) compared to any storage (Table 2 ). However, when analyzing the seed storage, there has been a superiority of the air conditioned room environment as well as in a dry and cold chamber, despite the reduction in germination to 54 and $57 \%$ (p $<0.05$ ) at 300 days of storage, representing an average loss of about $28 \%$ of the germination potential in relation to non-stored seeds (time zero) (Table 2). The germination of the seeds stored in the wet and cold chamber was low (38\%), matching the $45 \%$ reduction of the germination potential compared to non-stored seeds. Thus, seeds of Handroanthus heptaphyllus that are not used soon after harvesting, must be stored for later use; however, the wet and cold chamber environment is not suitable for this species.

In assessing the germination speed index (GSI), the means of the non-stored seeds treatments, kept in an air conditioned room and in a dry and cold chamber have not differed (Table 2), confirming the maintenance of seed vigor after storage, despite the tendency to reduce the GSI after storage. The result of the vigor also supports the storage superiority of ACR and DCC, regarding WCC. On the other hand, this rate was not enough to detect the difference between seeds non-stored and stored in ACR and DCC. It is suggested that there might be GSI inefficiency to identify differences between lots of Handroanthus heptaphyllus, having in this study the percentage of germination as one of the most robust variables to express the physiological ability of the seed. 
The percentage of dead seeds was higher in the wet and cold chamber, representing $61 \%$ of mortality, differing from the other treatments (Table 2), suggesting that the temperature and high humidity may have damaged the seeds and consequently there were more fungi associated to the seeds in this storage condition (Table 3).

Table 2. Mean values of normal seedlings (G), germination speed index (GSI), abnormal seeds (AS) and dead seeds (DS) and mass electrical conductivity (EC) of Handroanthus heptaphyllus (Mart.) Mattos, of the non-stored seeds and after 300 days of storage.

\begin{tabular}{cccccc}
\hline Treatment & $\mathrm{G}^{1}(\%)$ & $\mathrm{GSI}^{1}$ & $\mathrm{AS}^{1}(\%)$ & $\operatorname{DS}^{1}(\%)$ & $\mathrm{EC}^{2 * *}\left(\mu \mathrm{S}^{1} \mathrm{~cm}^{-1} \cdot \mathrm{g}^{-1}\right)$ \\
\hline ACR & $57 \mathrm{~b}^{*}$ & $1.39 \mathrm{a}$ & $4^{\mathrm{ns}}$ & $39 \mathrm{~b}$ & $14.86 \mathrm{a}$ \\
WCC & $38 \mathrm{c}$ & $0.84 \mathrm{~b}$ & 1 & $61 \mathrm{a}$ & $13.40 \mathrm{a}$ \\
DCC & $54 \mathrm{~b}$ & $1.28 \mathrm{a}$ & 3 & $43 \mathrm{~b}$ & $16.19 \mathrm{a}$ \\
NS & $83 \mathrm{a}$ & $1.52 \mathrm{a}$ & 1 & $16 \mathrm{c}$ & $5.55 \mathrm{~b}$ \\
\hline Average & 58 & 1.25 & 2.25 & 39.75 & 12.50 \\
CV $(\%)$ & 13.72 & 13.76 & 147 & 23.64 & 17.09 \\
\hline
\end{tabular}

*Means followed by the same letter do not differ statistically at $5 \%$ of error probability by ${ }^{1}$ Scott-Knott test and ${ }^{2}$ Student's t test; ** 25 seeds and $50 \mathrm{~mL}$ of distilled water containing EC of $0.15 \mu \mathrm{S} / \mathrm{cm}^{-1} / \mathrm{g}^{-1}$; ns = non-significant; $\mathrm{CV}=$ coefficient of variation; ACR (air conditioned room, $18{ }^{\circ} \mathrm{C}$ and $49 \% \mathrm{RH}$ ); WCC (wet and cold chamber, $8{ }^{\circ} \mathrm{C}$ and $80 \% \mathrm{RH}$ ); DCC (dry and cold chamber, $7.5^{\circ} \mathrm{C}$ and $55 \% \mathrm{RH}$ ) and $\mathrm{NS}-$ non-stored seeds (control).

Table 3. Fungi associated to seeds of Handroanthus heptaphyllus (Mart.) Mattos, stored in different environments after 300 days of storage.

\begin{tabular}{cccc}
\hline \multirow{2}{*}{ Storage environment } & Aspergillus sp. & Cladosporium sp. & Fusarium sp. \\
\cline { 2 - 4 } & & $85 \mathrm{~b}$ & $82 \mathrm{~b}$ \\
\hline $1-$ ACR & $23 \mathrm{a}^{*}$ & $55 \mathrm{a}$ & $23 \mathrm{a}$ \\
2- WCC & $74 \mathrm{~b}$ & $47 \mathrm{a}$ & $9 \mathrm{a}$ \\
3- DCC & $15 \mathrm{a}$ & 62.33 & 38.00 \\
Average & 37.33 & 17.67 & 26.37 \\
CV (\%) & 23.82 & & \\
\hline
\end{tabular}

*Means followed by the same letter do not differ significantly from each other by the Scott-Knott test at $5 \%$ of error probability. CV $=$ coefficient of variation; 1-ACR: air conditioned room, $18{ }^{\circ} \mathrm{C}$ and $49 \% \mathrm{RH}, 2-\mathrm{WCC}$ : wet and cold chamber, $8{ }^{\circ} \mathrm{C}$ and $80 \% \mathrm{RH}$ and $3-\mathrm{DCC}$ : dry and cold chamber, $7.5^{\circ} \mathrm{C}$ and $55 \% \mathrm{RH}$.

The electrical conductivity (EC) after storage compared to time zero confirms the reduction of seed vigor of ipê-roxo seeds (Table 2). However, it does not distinguish the different storage conditions because a mass test has been applied, and thus a deteriorated seed present in each sample preparation may have shrouded the result. Thus, it is suggested that EC be performed individually for each seed. Marcos-Filho (2005) infers that the EC test has as its principle the increase of the permeability of the membrane as the seeds decay. Thus, the higher the measured value, the higher is the amount of leached electrolytes (sugars, amino acids, proteins, among others) of the seed tissues for the water.

Thus, the results for electrical conductivity were not able to detect changes in vigor of seeds of Handroanthus heptaphyllus in different storage environments, and this result was found by Borba Filho and Perez (2009).

In the assessment of seed health held in seeds of Handroanthus heptaphyllus at 300 days after storage in different environments (ACR, WCC and DCC), ten different genera of fungi were found: Cladosporium sp., Alternaria sp., Penicillium sp., Fusarium sp., Aspergillus sp., Epicoccum sp., Bipolaris sp., Phomopsis sp., Rhizopus sp. and Pestalotia sp.

The highest incidence was of Cladosporium sp. (85 and 55\%) and Fusarium sp. (82 and 23\%) for seeds stored in an air conditioned room and in a wet and cold chamber, respectively. In the latter storage environment was found the highest percentage of Aspergillus sp. (74\%) (Table 3). For other fungal genera there was no significant difference between air conditioned room, wet and cold chamber and dry and cold chamber.

The occurrence of Aspergillus sp. was higher when associated with wet and cold chamber storage and may have occurred because of the high humidity of the place, which has favored the emergence of this pathogen. Botelho et al. (2008) have identified and quantified 16 genera of fungi associated with seeds of Handroanthus serratifolius (ipê-amarelo, commonly known as yellow lapacho, pau d'arco, yellow poui, yellow ipe, pau d'arco amarelo, or ipê-amarelo), among these: 
Cladosporium sp., Fusarium sp., Penicillium sp., Aspergillus sp. Fungi of the genera Aspergillus, Penicillium and Rhizopus are considered to cause damage to storage conditions. Cherobini et al. (2008) explain that the Penicillium and Aspergillus genera have the ability to reduce seed germination and cause the death of the embryo, but when they have low moisture contents, near the lower limit for the growth of the fungi, the attack is slow; however, as the humidity of the seed increases, the loss of germination becomes more rapid because of the rapid growth of the fungus. Analyzing the results together, it was observed that the species soon after seed harvest has a high initial germination $(\approx 80 \%)$, which can be seen in germination tests using substrates such as on and between sand and vermiculite, on and between blotting paper and filter. However, storage in a low humidity controlled environment $(\leq 55 \%)$ and temperature $\left(\leq 18{ }^{\circ} \mathrm{C}\right)$, although with a proportional loss of about 28 percentage points of the initial germination potential, maintain $55 \%$ of the viable seeds, ensuring availability of seedlings between annual collections, but with greater cost to the producer. In addition, the seed water content (WC) obtained at time zero and after storage, associated with the germination result, suggests that the seeds of Handroanthus heptaphyllus do not show a typical behavior of recalcitrant seeds, nor orthodox ones, and this study has found that the species mentioned has an intermediate trend between both classifications in relation to desiccation.

Storage analysis by the Pearson (r) correlation matrix was performed according to Callegari-Jacques (2003) and these can be seen in Table 4.

Table 4. Simple correlation (r) between variables of physiological and sanitary quality of seeds of Handroanthus heptaphyllus (Mart.) Mattos after 300 days of storage.

\begin{tabular}{|c|c|c|c|c|c|c|c|c|}
\hline Variable & Sto & $\mathrm{G} \%$ & GSI & $\mathrm{AS} \%$ & DS $\%$ & $\mathrm{Cla}$ & Fus & $A s p$ \\
\hline Sto & 1.00 & & & & & & & \\
\hline $\mathrm{G} \%$ & $-0.11^{\mathrm{ns}}$ & 1.00 & & & & & & \\
\hline GSI & $-0.15^{\mathrm{ns}}$ & $0.97^{*}$ & 1.00 & & & & & \\
\hline $\mathrm{AS} \%$ & $-0.12^{\mathrm{ns}}$ & $0.44^{\mathrm{ns}}$ & $0.46^{\mathrm{ns}}$ & 1.00 & & & & \\
\hline DS $\%$ & $0.12^{\mathrm{ns}}$ & $-0.97 *$ & $-0.96^{*}$ & $-0.63 *$ & 1.00 & & & \\
\hline $\mathrm{Cla}$ & $-0.82 *$ & $0.29^{\mathrm{ns}}$ & $0.31^{\mathrm{ns}}$ & $0.21^{\mathrm{ns}}$ & $-0.30^{\mathrm{ns}}$ & 1.00 & & \\
\hline Fus & $-0.91 *$ & $0.32^{\mathrm{ns}}$ & $0.39^{\mathrm{ns}}$ & $0.20^{\mathrm{ns}}$ & $-0.33^{\mathrm{ns}}$ & $0.90 *$ & 1.00 & \\
\hline$A s p$ & $-0.12^{\mathrm{ns}}$ & $-0.80 *$ & $-0.84 *$ & $-0.47^{\mathrm{ns}}$ & $0.81^{*}$ & $-0.19^{\mathrm{ns}}$ & $-0.20^{\mathrm{ns}}$ & 1.00 \\
\hline
\end{tabular}

*Significant at 5\%; ns = non-significant; Sto = storage; G\% = percentage of germination; GSI = germination speed index; AS $\%=$ percentage of abnormal seedlings; DS $\%=$ percentage of dead seeds; Cla = Cladosporium sp.; Fus = Fusarium $\mathrm{sp} . ;$ Asp = Aspergillus $\mathrm{sp}$.

The storage has a correlation that is considered strong and strongly, respectively, with pathogens Cladosporium sp. (-0.82) and Fusarium sp. (-0.91); these values occur because of the storage time, which suggests an increase in the percentage of pathogens associated with the seeds. The germination percentage correlates strongly and positively with GSI (0.97), and this confirmation is expected, since these parameters infer about the proper quality of the seeds. For the percentage of dead seeds (DS) and Aspergillus sp. with the percentage of germination, the correlation is negative $(-0.97$ and -0.80 , respectively), because as it decreases the germination percentage, the incidence of mortality of seeds and of said pathogen increases (Table 4). The values that associate the germination percentage with other variables follow the same trend as in a study conducted by Cherobini et al. (2008), in which the authors infer a higher germination linked to higher GSI and a lower incidence of dead seeds and of Aspergillus sp. in cedar seeds.

The correlation infers that the GSI is strongly and inversely correlated with the dead seeds percentage $(-0.96)$ and with Aspergillus sp. (-0.84) (Table 4).

The percentage of abnormal seedlings has a strong negative correlation with the percentage of dead seeds $(-0.63)$, indicating that when one of the variables increases the other one decreases. Dead seeds positively correlate with the pathogen Aspergillus sp. (0.81), which indicates that the higher the incidence of this fungus, the higher the mortality of the seeds. Finally, Cladosporium sp. and Fusarium sp. have a strongly positive correlation (0.90), which implies the association of both pathogens with the seeds of Handroanthus heptaphyllus (Table 4).

\section{Conclusions}

The seed germination test of Handroanthus heptaphyllus can be performed using seeding between blotting paper, between vermiculite, on sand, between sand, on vermiculite and between filter paper.

The storage of the seeds in plastic bags maintained in an 
air conditioned room environment and/or in a dry and cold chamber is suitable for the preservation of Handroanthus heptaphyllus seeds for a period of 300 days.

The packaging in a dry and cold chamber environment has provided a lower incidence of fungi associated with the seeds of Handroanthus heptaphyllus.

\section{Acknowledgement}

To CNPq for the scholarship granted to the second author.

\section{References}

BARNETT, H.L.; HUNTER, B.B. Illustred genera of imperfect fungi. 3ed. Minnesota: Burgess Publishing Company, 1999. 241 p.

BORBA FILHO, A.B; PEREZ, S.C.J.G.A. Armazenamento de sementes de ipê-branco e ipê-roxo em diferentes embalagens e ambientes. Revista Brasileira de sementes, v.31, n.1, p.259-269, 2009. http://dx.doi.org/10.1590/ S0101-31222009000100029

BOTELHO, L.S.; MORAES, M.H.D.; MENTEN, J.O.N. Fungos associados às sementes de ipê-amarelo (Handroanthus serratifolius) e ipêroxo (Handroanthus impetiginosus): incidência, efeito na germinação e transmissão para as plântulas. Revista Summa Phytopathology, v.34, n.4, p.343-348, 2008. http://www.scielo.br/pdf/sp/v34n4/v34n4a08.pdf

BRASIL. Ministério da Agricultura, Pecuária e Abastecimento. Regras para análise de sementes. Ministério da Agricultura, Pecuária e Abastecimento. Secretaria de Defesa Agropecuária. Brasília: MAPA/ACS, 2009a. 395 p. http:// www.agricultura.gov.br/arq_editor/file/2946_regras_analise_sementes.pdf

BRASIL. Ministério da Agricultura, Pecuária e Abastecimento. Manual de análise sanitária de sementes. Ministério da Agricultura, Pecuária e Abastecimento. Secretaria de Defesa Agropecuária, Brasília: MAPA ACS, 2009b. 202 p. http://www.agricultura.gov.br/arq_editor/file/12261_ sementes_-web.pdf

BRASIL. Ministério da Agricultura, Pecuária e Abastecimento. Instrução normativa $n^{o} 35$, de 14 de julho de 2011. http://sistemasweb.agricultura.gov.br/ sislegis/action/detalhaAto.do?method=consultarLegislacaoFederal. Accessed on Jan. $03^{\text {rd }} .2014$.

BRASIL. Ministério da Agricultura, Pecuária e Abastecimento. Instruções para análise de espécies florestais. Secretaria de Defesa Agropecuária. Brasília: MAPA/ACS, 2013. 98 p. http://www.agricultura.gov.br/arq_editor/
file/Laborat $\%$ C3\%B3rio/Sementes/FLORESTAL_documento_pdf.pdf

CALLEGARI-JACQUES, S.M. Bioestatística: princípios e aplicações. Porto Alegre: ARTMED, 2003. 255 p.

CARVALHO, L.R.; SILVA, E.A.A.; DAVIDE, A.C. Classificação de sementes florestais quanto ao comportamento no armazenamento. Revista Brasileira de Sementes, v.28, n.2, p.15-25, 2006. http://dx.doi.org/10.1590/ S0101-31222006000200003

CHEROBINI, E.A.I.; MUNIZ, M.F. B.; BLUME, E. Avaliação da qualidade de sementes e mudas de cedro. Revista Ciência Florestal, v.18, n.1, p.65-73, 2008. http:/coral.ufsm.br/cienciaflorestal/artigos/v18n1/A6V18N1.pdf

FERREIRA, D. F. SISVAR: a computer statical analysis system. Revista Ciência e Agrotecnologia, v.35, n.6, p.1039-1042, 2011. http://dx.doi org/10.1590/S1413-70542011000600001

GRINGS, M; BRACK, P. Handroanthus heptaphyllus (ipê-roxo) In BRASIL, Ministério do Meio Ambiente. Espécies nativas da flora brasileira de valor econômico atual ou potencial: plantas para o futuro - Região sul. Orgs: CORADIN, L; SIMINSKI, A.; REIS, A. Brasília: MMA, 2011. 934 p.

LORENZI, H. Árvores Brasileiras. São Paulo: Plantarum, 2002. v.1, 378 p.

MAGUIRE, J.B. Speed of germination-aid in selection and evaluation for seedling emergence vigor. Crop Science, v.2, n.2, p.176-177, 1962. https:// www.crops.org/publications/cs/abstracts/2/2/CS0020020176

MARCOS-FILHO, J. Fisiologia de sementes de plantas cultivadas Piracicaba: FEALQ, 2005. 495 p.

SANTANA, D.G.; RANAL, M.A. Análise estatística na germinação. Revista Brasileira Fisiologia Vegetal, v.12, p.205-237, 2000. http://www.cnpdia. embrapa.br/rbfv/pdfs/v12Especialp206.pdf

SARMENTO, M.B.; VILLELA, F.A. Sementes de espécies florestais nativas do Sul do Brasil. Informativo Abrates, v.20, n.1,2, p.39-44, 2010. http://www. abrates.org.br/portal/images/stories/informativos/v20n12/artigo05.pdf

VIEIRA, R.D. Teste de condutividade elétrica. In: VIEIRA, RD; CARVALHO, N.M. Teste de vigor em sementes. Jaboticabal: FUNEP, 1994 p. 103-132.

WIELEWICKI, A.P.; LEONHARDT, C.; SCHLINDWEIN, G.; MEDEIROS, A.C.S. Proposta de padrões de germinação e teor de água para sementes de algumas espécies florestais presentes na região Sul do Brasil. Revista Brasileira de Sementes, v.28, n.3, p.191-197, 2006. http://dx.doi.org/10.1590/ S0101-31222006000300027 